\title{
Junglerice (Echinochloa colona L.) seedling emergence model as a tool to optimize pre-emergent herbicide application
}

\author{
Gabriel Picapietra, ${ }^{1,2}$ Horacio A. Acciaresi ${ }^{1,3}$ \\ ${ }^{1}$ National Institute of Agricultural Technology - Pergamino Agricultural Experimental Station, Pergamino; \\ ${ }^{2}$ National University of the Northwest of the Province of Buenos Aires, School of Agricultural, Natural and \\ Environmental Sciences, Buenos Aires; ${ }^{3}$ Commission for Scientific Research of the Province of Buenos \\ Aires (CIC), Argentina
}

\begin{abstract}
Highlights
- Weed occurrence indirectly increases the number of herbicide applications in Argentina.

- Reducing the number and volume of herbicide applications contributes to mitigating environmental impact in the short term.

- There is a critical time during weed emergence in which chemical control via herbicide application is most effective.

- Seedling emergence models are useful management tools to predict critical timing for weed control.
\end{abstract}

\begin{abstract}
Junglerice (Echinochloa colona), one of the worst and most problematic weeds globally, causes significant economic losses due to yield loss and control cost increase. Taking into account that this weed emerges in approximately five months - from September to January -, and considering that reducing herbicide use is key in the current intensification of agricultural production systems, the present study was carried out under the hypothesis that there should be an optimal moment for pre-emergent herbicide application to achieve maximum weed control effectiveness and efficiency. Therefore, experiments were carried out from August 2016 to January 2021 in Pergamino, Buenos Aires province, Argentina, using a double-logistic emergence model of junglerice seedlings. Bicyclopyrone plus s-metolachlor, clomazone, and pyroxasulfone plus saflufenacil were applied at different times between 92 and 478 growing degree days (GDDs). Single applications between 348 and 399 GDD were observed to reduce
\end{abstract}

Correspondence: Gabriel Picapietra, Instituto Nacional de Tecnología Agropecuaria - Estación Experimental Agropecuaria Pergamino, Av. Pte Arturo Frondizi km 4.5, 2700 Pergamino, Argentina.

E-mail: picapietra.gabriel@inta.gob.ar

Key words: Chemical weed control; critical timing; residual herbicides.

Received for publication: 23 November 2020.

Revision received: 18 February 2021.

Accepted for publication: 19 February 2021.

(C) Copyright: the Author(s), 2021

Licensee PAGEPress, Italy

Italian Journal of Agronomy 2021; 16:1845

doi:10.4081/ija.2021.1845

This article is distributed under the terms of the Creative Commons Attribution Noncommercial License (by-nc 4.0) which permits any noncommercial use, distribution, and reproduction in any medium, provided the original author(s) and source are credited. junglerice seedling emergence by $85-99 \%$, depending on the herbicide used. Such a seedling emergence reduction could be a convenient strategy to provide significant weed suppression in the field in combination with a competitive crop and within a sustainable production system. The results of the present study lead to the conclusion that using predictive models for pre-emergent herbicide applications ensures more effective use of herbicides and reduces the amounts of herbicides used and the risks of selecting herbicide-resistant junglerice populations.

\section{Introduction}

Herbicides are failing worldwide to do the job for which they have been designed because weeds have evolved resistance to them, which poses significant challenges to weed management (Chauhan, 2020). Nonetheless, they are increasingly used as the primary solution to the numerous problems resulting from weed control, making herbicidal use a less economically profitable practice and with a tremendous negative impact on the environment (Stewart et al., 2011). The negative impacts caused by indiscriminate herbicide use are the major aggravating factors that drastically affect the environment, product safety, and human health (Zhu et al., 2020) on the one hand, and the loss of weed susceptibility to herbicide control (Beckie, 2020), on the other. In such a scenario, it urges that changes be implemented to rationalize weed management, focusing on sustainable herbicide use to reduce not only their use but also the negative impacts they have on the community and the environment. Weed biology would be a key tool to reducing herbicide use by determining critical timing for weed control (Nazarko et al., 2005).

Compared to multiple herbicide applications, timely applications of pre-emergent herbicides reduce environmental impact and improve the profitability and efficacy of weed control (Wiles, 2004). Seedling emergence models can be employed to optimize herbicide use within a decision support system (DSS) (GonzálezAndújar et al., 2011). Despite numerous investigations on the development of seedling emergence models (Forcella et al., 2000; Grundy, 2003; González-Andújar et al., 2016), they have not yet been adopted as weed control tools due to the complexity of their 
adjustment and the nature of data required for their prediction (Grundy, 2003). Nonetheless, there are simple and easy-to-use air temperature-based seedling emergence models that have acceptable goodness of fit and prediction accuracy (Myers et al., 2004; De Corby et al., 2007; Izquierdo et al., 2009).

Among weeds, junglerice (Echinochloa colona L. Link) is considered one of the worst weeds in the world (Rao et al., 2007; Peerzada et al., 2016). In Argentina, it is the most predominant weed in soybean monoculture fields, which requires from three to five herbicide applications per growing cycle, including glyphosate and acetyl CoA carboxylase (ACCase)-inhibiting herbicides (Principiano and Acciaresi, 2017). Junglerice emergence cycle occurs in approximately five months - from September to January. Therefore, considering that reducing herbicide use is mandatory in the current intensification of agricultural production systems, the present study was carried out under the hypothesis that there should be an optimal moment for pre-emergent herbicide application to achieve maximum herbicidal effectiveness and efficiency in junglerice control.

Timely herbicide application could significantly help to: i) optimize herbicide application schedules; ii) attain the highest use efficiency and effectiveness; and iii) reduce the number of interventions during the crop growing cycle. Therefore, a seedling emergence model for junglerice was tested in the present study to evaluate its potential as a tool to optimize pre-emergent herbicide application.

\section{Materials and methods}

Experiments were carried out between September 2016 and January 2021 at the Instituto Nacional de Tecnología Agropecuaria (INTA) (Pergamino, Buenos Aires province, Argentina, $33.95^{\circ} \mathrm{S}$, $60.57^{\circ} \mathrm{W}, 56 \mathrm{~m}$ asl). Due to crop rotation, experiments were conducted in the 2016/17 and 2017/18 corn growing seasons and in the 2018/19 and 2020/21 soybean growing seasons. Herbicide treatments were therefore repeated in each crop twice.

One pre-emergent treatment in corn and two in soybean were applied at different times during the junglerice seedling emergence period. Seedling emergence was calculated using the following predictive model (Eq. 1):

$$
E M=47.42+\frac{52.04}{1+1.39 * e^{(-0.04 *(G D D-123.3))}}-\frac{52.04}{1+7.8 * e^{(0.007 *(G D D-186))}}
$$

it was fitted to the study area (Picapietra et al., 2020). In this nonlinear model, the beginning of the thermal time sum was in late August, when the mean air temperature was lowest, below the base temperature $\left(10^{\circ} \mathrm{C}\right)$.

Thermal time was calculated as growing degree days (GDDs) using temperature forecasts (SMN, 2021), and herbicide applications were scheduled. GDDs were subsequently calculated using actual air temperature data provided by the INTA Agrometeorology station in Pergamino. GDDs sum started on $8 / 21,8 / 20,8 / 31$, and $9 / 2$ in $2016,2017,2018$, and 2020, respectively.

\section{Experimental design and herbicide application}

The experiment was conducted under a randomized complete block design with a split-plot arrangement. Application timing was the main plot and herbicides treatment the subplot. Pre-emergent herbicides (Table 1) were sprayed with compressed air (1.7 bar) experimental sprayer in $15 \mathrm{~m}$ long by $2 \mathrm{~m}$ wide subplots. A spray volume of $115 \mathrm{~L} \mathrm{ha}^{-1}$ and six 8001 flat fan nozzles spaced $33.3 \mathrm{~cm}$ apart were used. In order to control the emerged weeds at the time of herbicide application, glyphosate potassium salt $860 \mathrm{~g}$ ae ha-1 was added to the sprayer mixture.

Herbicide applications began in late September when weather conditions allowed, coinciding with the application time of presowing herbicides in fields in the surrounding area. The first herbicide treatment for each season was applied on 9/21, 9/25, 9/30, and $9 / 28$ in 2016, 2017, 2018, and 2020, respectively, and the last application timing was model-estimated around $90 \%$ of the seedling emergence (430 GDDs). With the date of the first and last application defined, the remaining ones were distributed homogeneously in the period (Figure 1).

Although four application timings were scheduled for the first two seasons, the fourth application timing of the second season was not considered based on prediction falling after 500 GDDs, and therefore none of the corresponding emerged weeds were controlled. Given this, five application timings before 500 GDDs were scheduled for the last two seasons. The first application of saflufenacil plus pyroxasulfone in 2018 was not considered because replications were lost for reasons unrelated to the experiments.

Table 1. Herbicides used, active ingredients (herbicide), and the dose applied (Dose, ai ha ${ }^{-1}$ ) in each corn season $(2016 / 17$ and 2017/18) and soybean season (2018/19 and 2020/21).

\begin{tabular}{lcc} 
Crop & Herbicide & Dose $\left(\right.$ ai ha $\left.^{-1}\right)$ \\
& bicyclopyrone & $200 \mathrm{~g}$ \\
Corn & + s-metolachlor & $+960 \mathrm{~g}$ \\
& + glyphosate & $+860 \mathrm{~g}$ \\
& clomazone & $720 \mathrm{~g}$ \\
Soybean & + glyphosate & $+860 \mathrm{~g}$ \\
\cline { 2 - 3 } & pyroxasulfone & $170 \mathrm{~g}$ \\
& + saflufenacil & $+31.5 \mathrm{~g}$ \\
& + glyphosate & $+860 \mathrm{~g}$ \\
\hline
\end{tabular}

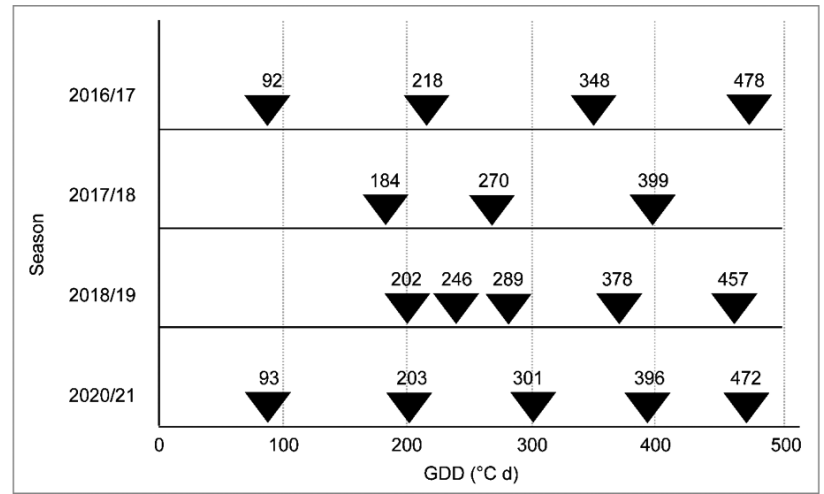

Figure 1. Application timing of different herbicide treatments (triangles, growing degree days - GDDs) according to the air temperature-based double-logistic seedling emergence model (Picapietra et al., 2020). Bicyclopyrone plus s-metolachlor for each corn season (2016/17 and 2017/18) and clomazone and pyroxasulfone plus saflufenacil for each soybean season $(2018 / 19$ and 2020/21). 


\section{Crop planting}

During the experiments, glyphosate-resistant corn and soybean were cultivated under a no-tillage system. Crop management was similar every year, i.e., a foliar herbicide in August was applied, treatments were subsequently applied at different times, and finally, the crop was sown in early December.

Crop planting was performed in the back half of the plots to avoid the direct disturbance of seed drills on the seedling count. Corn and soybean were seeded at densities of 8.5 plant $\mathrm{m}^{-2}$ and 32 plant $\mathrm{m}^{-2}$, respectively, and at a row spacing of $0.70 \mathrm{~m}$ and $0.52 \mathrm{~m}$, respectively.

\section{Seedling counts}

Emerged seedlings were counted in triplicate every 15 days in three $0.5 \times 0.35 \mathrm{~m}$ permanent sections located randomly within the front half of the plots. After each counting, plants were carefully removed with minimum soil disturbance. In the non-treated plots, counting began in early September, at the beginning of the emergence period (Picapietra et al., 2020), whereas in the herbicidetreated plots counting began after herbicide application.

\section{Cumulative relative emergence and effective control period}

Cumulative relative emergence (Er) was calculated with data resulting from the following equation (Eq. 2):

$$
E r_{i}=\frac{\sum\left(E_{0 . . .} E_{i}\right)}{E_{n}} \cdot 100
$$

where $E r_{i}$ is the cumulative relative emergence (\%) at time $i, E$ is the number of seedlings from the beginning $\left(E_{0}\right)$ to time $i\left(E_{i}\right)$, and $E_{n}$ is the total number of emerged seedlings in the corresponding section of the untreated plot.

To determine the effective control period (EC), GDDs were calculated from the beginning of the emergence cycle to the emergence of new seedlings after herbicide application (Figure 2). In addition, foliar control, and residual control were considered.

\section{Statistical analysis}

The data corresponding to the different application timings of each herbicide were analysed. This was due to the fact that our interest was not focused on determining which herbicide was the best but on determining which timing was the best for herbicide application in junglerice seedlings. Thus, as different herbicides and crops were included in the present study, and considering a significant year-application timing interaction, the data collected were analysed per herbicide and per year separately.

A generalized linear mixed model (GLMM) was fitted through a repeated measures design to assess the effect of application time on Er. The application timing factor, time factor as GDD, and the interaction between them were included as fixed effects, whereas replication and application timing were considered random crossover effects (Di Rienzo et al., 2017).

One-way ANOVA analysed EC values as only application timing was considered. Means were separated by the LSD test $(\mathrm{P}<0.05)$. In addition, normality and variance homogeneity assumptions were checked. Analyses were performed using the statistical software Infostat ver. 2020p (Di Rienzo et al., 2020).

\section{Results}

During the experimental period, December was wetter than the ten-year average, except for the last experimental cycle (2020/21), in which monthly rainfall was below the historical average. It is also worthy of note that whereas August was $3.0^{\circ} \mathrm{C}$ warmer than the ten-year average both in 2017/18 and 2020/21, November $2017 / 18$ was $3.3^{\circ} \mathrm{C}$ colder (Figure 3 ).

\section{Bicyclopyrone plus s-metolachlor}

In the 2016/17 season, maximum efficiency of the mixture bicyclopyrone plus s-metolachlor was achieved when applied at 348 GDD due to lower Er observed (2\%) (Figure 4). This application timing was different from the other application timings evaluated $(\mathrm{P}<0.05)$. In the following season, only $3 \%$ of seedling emergence was recorded in the plots treated at 399 GDDs. Also, these application timings achieved the maximum EC values of 1282 and 993 GDDs in the $2016 / 17$ and $2017 / 18$ seasons, respectively (Figure 5).

\section{Pyroxasulfone plus saflufenacil}

In the 2018/19 season, no differences between the applications of pyroxasulfone plus saflufenacil at 378 or 457 GDDs were observed. These plots showed an average ranging between 4 and $5 \%$ of cumulative seedling emergence (Figure 6). These application timings were also showed the higher EC for the season (998

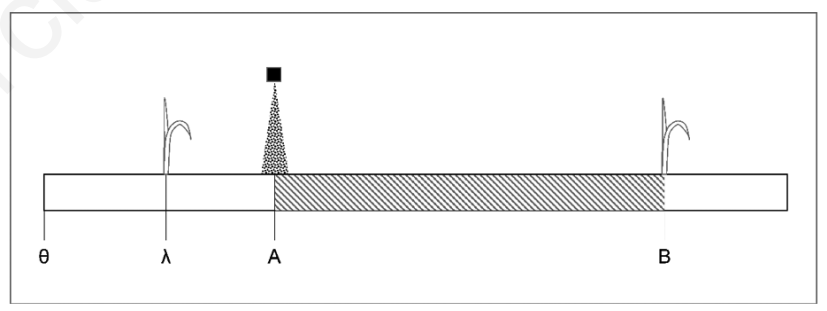

Figure 2. Diagram of effective control period calculated from the beginning of the GDDs sum $(\theta)$ until the emergence of new seedlings $(B)$, including seedling emergence onset $(\lambda)$ and herbicide application time (A).

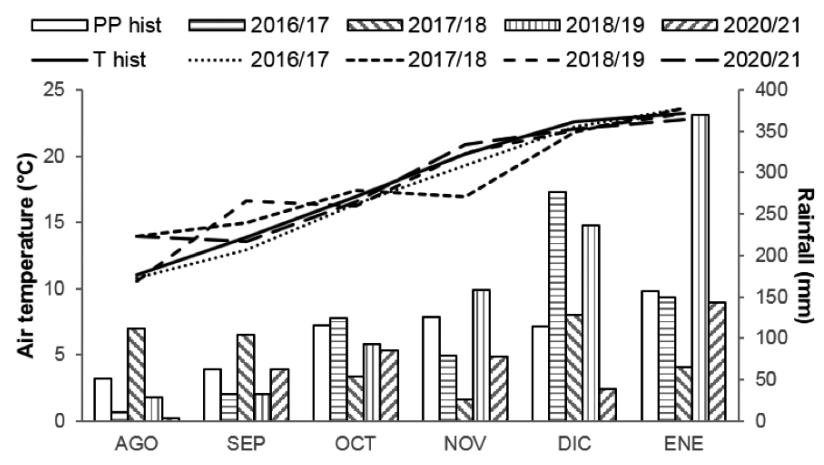

Figure 3. Monthly mean air temperature values (lines, ${ }^{\circ} \mathrm{C}$ ) and monthly rainfall values (bars, $\mathrm{mm}$ ) from August to January corresponding to the four years of this study (2016/2017, $2017 / 2018,2018 / 2019$, and $2020 / 2021$ ) and the ten-year-average $(2006 / 2007-2015 / 2016)$. 
and 913 GDDs, respectively) (Figure 7). At other application timings, Er was higher than 35\%, and EC was 678 GDDs. In the 2020/21 season, maximum seedling control was achieved in the treated plots at 396 GDDs, seedling emergence was on average 4\%, and EC was 1092 GDDs. An Er higher than 18\% and an EC lower than 405 GDDs were also observed, thus indicating that the herbicide mixture application was ineffective before 396 GDDs (Figures 6 and 7).

\section{Clomazone}

Junglerice control was maximum when clomazone was applied at 457 and 472 GDDs in the 2018/2019 and 2020/2021 seasons, respectively. At these application timings, cumulative seedling emergence was $15 \%$ (Figure 8), and EC was 913 and 770 GDDs in the 2018/19 and 2020/21 seasons, respectively (Figure 9).

The remaining application timings evaluated were found not to be optimal for junglerice control. Er in the clomazone-treated plots before 457 and 472 GDDs in the 2018/19 and 2020/21 seasons was higher than $22 \%$ and $24 \%$, respectively.

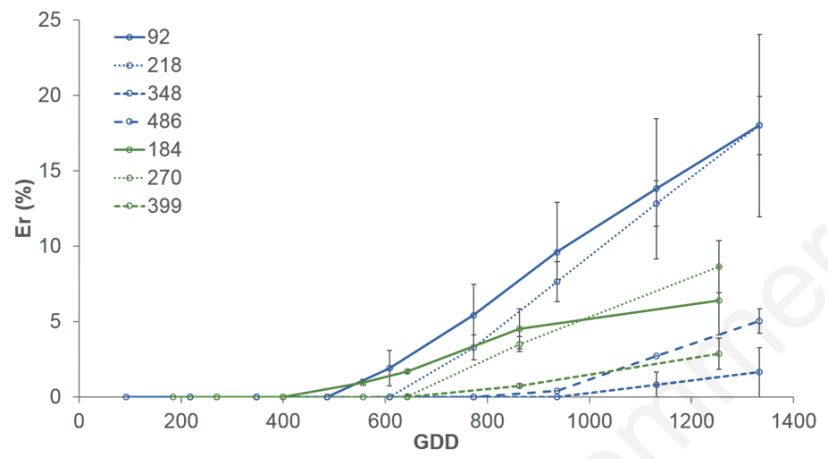

Figure 4. Cumulative relative emergence (Er) of junglerice seedlings analysed independently in 2016/17 (blue) and 2017/18 (green) seasons. Comparison of different bicyclopyrone plus smetolachlor application timings (lines referenced in the figure). GDD, growing degree days.

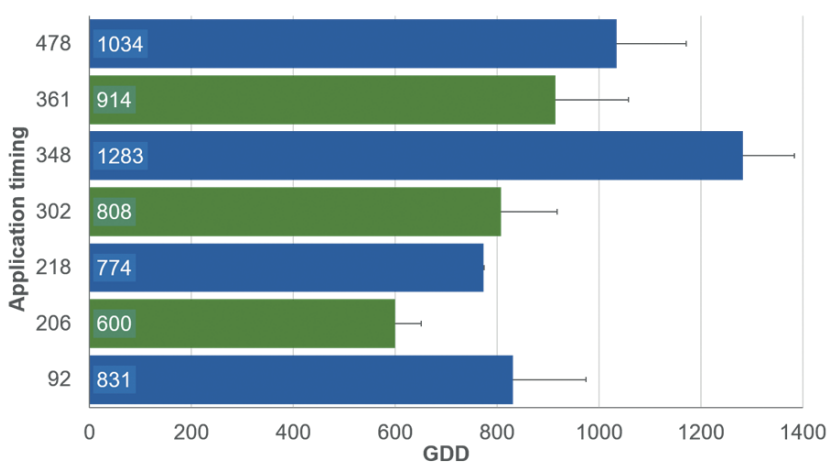

Figure 5. Effective control period (EC, growing degree days GDDs) of bicyclopyrone plus s-metolachlor during different cycles of junglerice emergence analysed independently in 2016/17 (blue) and 2017/18 (green) seasons.

\section{Discussion}

\section{Herbicide use}

As the herbicides bicyclopyrone and s-metolachlor have no foliar action (Lewis et al., 2016), glyphosate was the only herbicide in the mixture responsible for the control of emerged plants. In this sense, the application at 478 GDDs in the first experimental season was not effective due to the deficient foliar control on the plants with significant development, which corresponds to the first emerged cohorts.

The combined use of pyroxasulfone with saflufenacil was effective at up to 378 and 396 GDDs in the two years evaluated. The application of this mixture at 472 GDDs in 2020/21, despite being the latest, achieved good control of junglerice probably as a result of the joint foliar effect of glyphosate and saflufenacil. However, a lower residual control was observed probably because of herbicidal binding to larger plants (Congreve and Cameron, 2019).

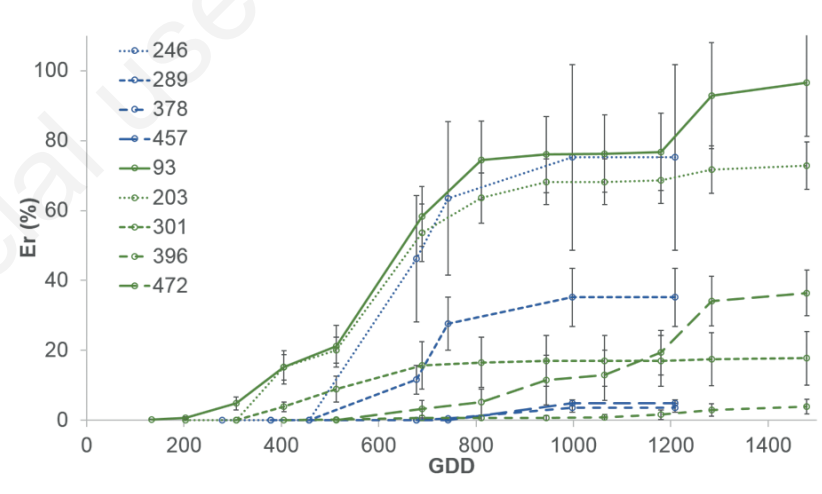

Figure 6. Cumulative relative emergence (Er) of junglerice seedlings analysed independently in 2018/19 (blue) and 2020/21 (green) seasons. Comparison of different application timings of pyroxasulfone plus saflufenacil. GDD, growing degree days.

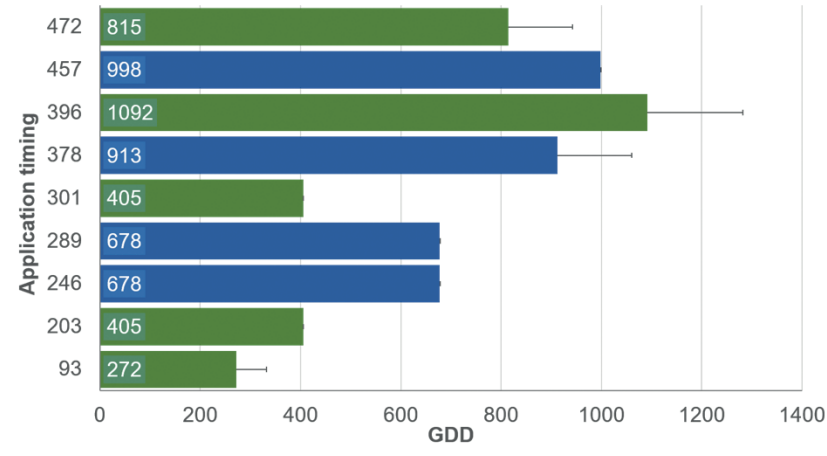

Figure 7. Effective control period (EC, growing degree days GDDs) of pyroxasulfone plus saflufenacil during different cycles of junglerice emergence analysed independently in 2018/19 (blue) and 2020/21 (green) seasons. 
As to the herbicide clomazone, previous research has recommended a rate ranging between 960 and $1200 \mathrm{~g}$ ai ha ${ }^{-1}$ to increase weed control percentage (Esqueda, 1999). However, while the herbicides evaluated in the present study yielded a similar EC, a high number of seedlings were observed in the clomazone-treated plots by the end of the study. This could indicate that herbicide soil persistence is limited in agreement with Lewis et al. (2016), who observed that the minimum loss time of $90 \%$ of the initial herbicide (dt90) was 65-day long. In this connection, it should be noted that the $\mathrm{dt} 90$ is also affected by microbial degradation in warm and humid soils (Santos et al., 2008).

Although clomazone application either before or immediately after weed emergence was observed not to yield efficient control over junglerice, the most effective applications were the last ones. This coincides with previous observations by Esqueda (2000), who reported a slightly lower control effect than that in the pre-emergence stage between the second and fourth unfolded leaves in clomazone-treated plots (Esqueda, 2000).

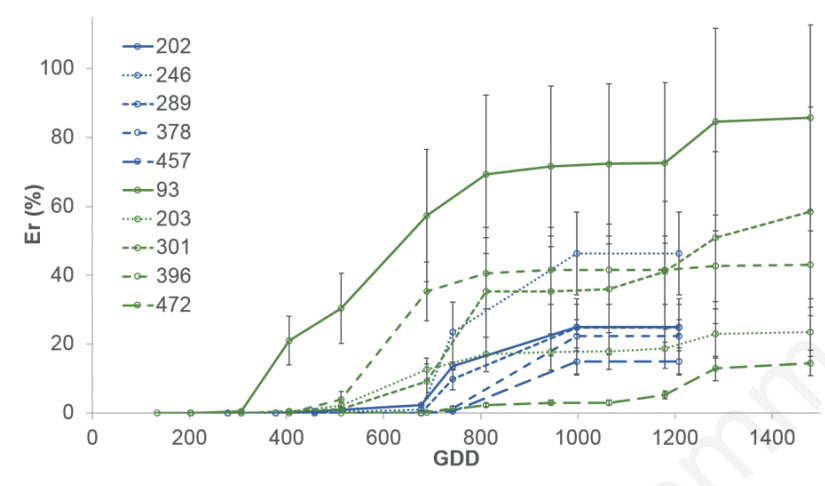

Figure 8. Cumulative relative emergence (Er) of junglerice seedlings analysed independently in 2018/19 (blue) and 2020/21 (green) seasons. Comparison of different application timings of clomazone (lines referenced in the figure). GDD, growing degree days.

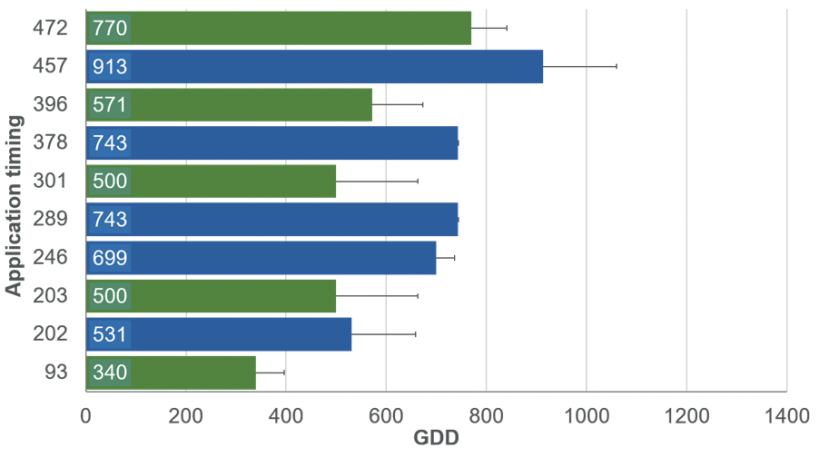

Figure 9. Effective control period (EC, growing degree days GDDs) of clomazone during different cycles of junglerice emergence analysed independently in 2018/19 (blue) and 2020/21 (green) seasons.

\section{Emergence predictive model as a decision-support tool}

The double-logistic model of junglerice emergence can predict emergence cycles across years (Picapietra et al. 2020) using air temperature values which can be estimated from weather forecast data. This tool improves chemical weed control efficiency and reduces the number of herbicide applications in a crop sequence. In other words, adequate control can be achieved with a single herbicide application if precisely timed were implemented (Principiano and Acciaresi, 2017).

Furthermore, this double-logistic model provides insight into the demographic process of junglerice and therefore makes it feasible to reduce the number of herbicide applications during crop growing cycles. It can thus be considered an effective and sustainable weed management tactic (Chauhan, 2020). However, despite the high efficiency observed by a single timely application, this is only a strategy to improve the herbicide use, and it must be integrated into a weed management program. Inadequate use of this knowledge could lead to selecting herbicide-resistant weeds, favoured by pre-emergent herbicides selection-pressure.

\section{Conclusions}

The results obtained here indicate that an emergence model based on thermal time permits adjust herbicide applications improving their efficiency and effectiveness. This, in turn, contributes to reducing the number of applications and the volume of herbicides.

Herbicide application efficiency was found to be highest shortly before reaching 400 GDDs from the beginning of the emergence cycle of junglerice. Thus, 400 GDDs could be set as the critical timing to junglerice control with a mixture of residual herbicides and foliar herbicides. Further research aiming at exploring herbicides other than those analysed in the present study was needed, and analysing the rotation of herbicides with different mechanisms of action will contribute to reducing the risk of selecting herbicideresistant junglerice populations.

\section{References}

Beckie HJ, 2020. Herbicide resistance in plants. Plants 9:435.

Chauhan BS, 2020. Grand Challenges in Weed Management. Front. Agron. 1:3.

Congreve M, Cameron J, 2019. Soil behavior of pre-emergent herbicides in Australian farming systems - A national reference manual for agronomic advisers. 2nd ed. Grains Research and Development Corporation publication, Australia.

De Corby KA, Van Acker RC, Brule-Babel AL, Friesen LF, 2007. Emergence timing and recruitment of volunteer spring wheat. Weed Sci. 55:60-9.

Di Rienzo JA, Macchiavelli RE, Casanoves F, 2017. Modelos lineales generalizados mixtos: aplicaciones en InfoStat. 1st ed. Digital book, Córdoba, Argentina. 101 p.

Di Rienzo JA, Casanoves F, Balzarini MG, Gonzalez L, Tablada M, Robledo CW, 2020. InfoStat versión 2020p. Centro de Transferencia InfoStat, FCA, Universidad Nacional de Córdoba, Argentina.

Esqueda VA, 1999. Control de malezas en caña de azúcar con clomazone y ametrina. Agron. Mesoam. 10:23-30.

Esqueda VA, 2000. Control de malezas en arroz de temporal con 
clomazone, solo y en mezcla con propanil y 2,4-D. Agron. Mesoam. 11:51-6.

Forcella F, Benech-Arnold RL, Sanchez R, Ghersa CM. 2000. Modeling seedling emergence. Field Crop. Res. 67:123-39.

González-Andújar JL, Fernandez-Quintanilla C, Bastida F, Calvo R, Izquierdo J, and Lezaun JA, 2011. Assessment of a decision support system for chemical control of annual ryegrass (Lolium rigidum) in winter cereals. Weed Res. 51:304-9.

González-Andújar JL, Chantre G, Morvillo C, Blanco AM, Forcella F. 2016. Predicting field weed emergence with empirical models and soft computing techniques. Weed Res. 56:415-23.

Grundy A, 2003. Predicting weed emergence: a review of approaches and future challenges. Weed Res. 43:1-11.

Izquierdo J, González-Andújar JL, Bastida F, Lezaún JA, Sánchez del Arco MJ, 2009. A thermal time model to predict corn poppy (Papaver rhoeas) emergence in cereal fields. Weed Sci. 57:660-4.

Lewis KA, Tzilivakis J, Warner D, Green A, 2016. An international database for pesticide risk assessments and management. Hum. Ecol. Risk Assess. 22:1050-64.

Myers MW, Curran WS, Van Gessel MJ, Calvin DD, Mortensen DA, Majek BA, Karsten HD, Roth GW, 2004. Predicting weed emergence for eight annual species in the northeastern United States. Weed Sci. 52:913-9.

Nazarko OM, Van Acker RC, Entz MH, 2005. Strategies and tactics for herbicide use reduction in field crops in Canada: a review. Can. J. Plant Sci. 85:457-79.

Peerzada AM, Bajwa AA, Ali HH, Chauhan BS, 2016. Biology, impact, and management of Echinochloa colona (L.) Link. Crop Prot. 83:56-66.

Picapietra G, Acciaresi HA, and González-Andújar JL, 2020. Predicting junglerice (Echinochloa colona L.) emergence as a function of thermal time in the humid pampas of Argentina. Int. J. Pest Manage. [Epub ahead of print].

Principiano MA, Acciaresi HA, 2017. Costo financiero e impacto ambiental del control de malezas en diferentes secuencias de cultivos en el NO de la provincia de Buenos Aires. Rev. Tecnol. Agropec. 10:37-41.

Rao AN, Johnson DE, Sivaprasad B, Ladha JK, Mortimer AM, 2007. Weed management in direct-seeded rice. Adv. Agron. 93:153-255.

Santos FM, Marchesan E, Machado SLO, Avila LA, Zanella R, Gonçalves FF, 2008. Persistência dos herbicidas imazethapyr e clomazone em lâmina de água do arroz irrigado. Planta Daninha 26:875-81.

SMN, 2021. Servicio Meteorológico Nacional. Available from: https://www.smn.gob.ar/.

Stewart CL, Nurse RE, Van Eerd LL, Vyn RJ, Sikkema PH, 2011. Weed control, environmental impact, and economics of weed management strategies in glyphosate-resistant soybean. Weed Tech. 25:535-41.

Wiles LJ, 2004. Economics of weed management: principles and practices. Weed Tech. 18:1403-7.

Zhu Y, Wu J, Han L, Wang X, Li W, Guo H, Wei H, 2020. Nanozyme sensor arrays based on heteroatom-doped graphene for detecting pesticides. Anal. Chem. 92:7444-52. 